\title{
Praca wychowawczo-edukacyjna osób konsekrowanych jako element misji Kościoła
}

Ważny element misji Kościoła stanowi realizacja jego funkcji wychowawczej koncentrująca się na wychowaniu w wierze. W sposób szczególny w to dzieło włączają się osoby konsekrowane. Istotę ich specyficznego zaangażowania, jak i realizowanego wychowania katolickiego we wszystkich wymiarach jego integralności określają dokumenty papieskie, soborowe i Kongregacji Edukacji Katolickiej oraz oparte na nich wytyczne Kościoła lokalnego. Bogata praktyka realizacji działalności edukacyjnej przez osoby konsekrowane rozwija się od wieków zgodnie charyzmatami poszczególnych zgromadzeń, sięgając do tradycji i odpowiadając na współczesne wyzwania. Pozostając wierne swej tożsamości i podejmując zmiany adaptacyjne w zakresie pedagogii, wpisują się one także w misję wychowawczą diecezji tarnowskiej. Swym stylem życia i posługi starają się jasno wyrazić jej religijny charakter, dając świadectwo stałej łączności między Bogiem a człowiekiem. Jest to tym bardziej ważne dzisiaj, gdy społeczeństwo staje wobec dynamicznych przemian, zmieniających nie tylko jego zewnętrzny styl życia, lecz również duchowe nastawienie. W tych warunkach wielu ludzi spodziewa się, że Kościół wyrzeknie się swego posłannictwa i przyjmie nowe formy życia i działalności. Poglądy ludzi, ich kultura umysłowa i życie duchowe podlegają silnemu oddziaływaniu osiągnięć nauki i techniki, przemian życia społecznego, prądów filozoficznych i ideologii. W tym kontekście zgromadzenia zakonne, pozostając wierne swojemu charyzmatowi i misji, starają się realizować katolickie wychowanie 
w ramach parafii, jak również poprzez własne szkoły i inne placówki, we wspólpracy i za zgodą biskupa diecezjalnego.

\section{Osoby konsekrowane w realizacji funkcji wychowawczej Kościoła dzisiaj}

Wychowanie stanowi istotny element misji Kościoła. Osoby konsekrowane, które są powołane, aby na polu wychowawczym dawać radykalne świadectwo o dobrach królestwa, dostępnych dla każdego człowieka, mają w tej dziedzinie szczególne zadanie do spełnienia. Wezwane są do twórczej wierności, ,by pogłębiać swoje kwalifikacje i rozwijać dynamiczną wierność swej misji, przystosowując jej formy - gdy jest to konieczne - do nowych sytuacji i rozmaitych potrzeb, w postawie całkowitej uległości wobec Bożych natchnień

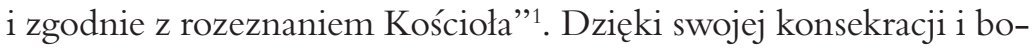
gatemu dziedzictwu tradycji wychowawczych osoby konsekrowane poświęcają się wielorakim dziełom, zrodzonym z chrześcijańskiej miłości. Szczególne doświadczenie darów Ducha Świętego, wsłuchiwanie się w słowo Boże i praktyka rozeznawania, pozwalające na głębokie poznawanie duchowej prawdy, sprawiają, że są one w stanie prowadzić szczególnie owocną działalność edukacyjną, wnosząc ważny wkład w pracę innych wychowawców ${ }^{2}$. W ten sposób osoby konsekrowane bogactwem swoich charyzmatów przyczyniają się do tego, że Kościól coraz głębiej urzeczywistnia swoją misję $e^{3}$.

Zgromadzenia, których charyzmatem jest prowadzenie działalności wychowawczej, poświęcają się, by tworzyć środowiska wychowawcze przeniknięte ewangelicznym duchem wolności i miłości, które pomagają młodym wzrastać w człowieczeństwie i są zaczynem komunii misyjnej w Kościele powszechnym. Ten zmysł kościelnej komunii i rozwijająca się duchowość komunii może skutecznie kształtować sposób myślenia, mówienia i działania, który sprawia, że Kościól rozrasta się w głąb i wszerz ${ }^{4}$. W tym kontekście wspólnota wychowawcza może stawać się doświadczeniem komunii i miejscem laski, w którym program

Jan Paweł II, Adh. apost. Vita consecrata (25.03.1996), nr 37 [dalej: VC].

Por. VC 96.

Por. VC 46.

1564 Zob. VC 46-47. 
pedagogiczny przyczynia się do połączenia w harmonijnej syntezie tego, co Boskie i ludzkie, Ewangelii i kultury, wiary i życia ${ }^{5}$.

Szeroko rozumiana edukacja jako harmonijne połączenie opieki nad najmłodszymi, wychowania i kształcenia jest procesem wzajemnej wymiany wartości i darów między wychowawcami i wychowankami. Jan Paweł II przypomniał, że

Historia Kościoła od starożytności aż do naszych czasów jest bogata we wspaniałe przykłady osób konsekrowanych, które wyrażały i nadal wyrażają swoje dążenie do świętości przez pracę pedagogiczną, ukazując zarazem świętość jako cel wychowania. Wiele z nich, pracując jako wychowawcy, rzeczywiście osiągnęło doskonałość miłości. Jest to jeden z najcenniejszych darów, jakie osoby konsekrowane mogą również dzisiaj ofiarować młodzieży, wychowując i otaczając ją miłościąa

Na tej drodze wspólnego podążania do pełni człowieczeństwa, pozostając odpowiedzialnymi za młodszych, słabszych, osoby konsekrowane mają szczególny obowiązek włączenia się w realizację wychowawczej funkcji Kościoła.

Podstawowy cel funkcji wychowawczej Kościoła wskazał Paweł VI nauczając, że ,ci, którzy obecnie są wychowawcami i nauczycielami w Kościele, powinni przypominać młodzieży katolickiej jej wielką godność i rodzący się stąd obowiązek życia w tym świecie, ale nie wedlug obyczajów tego świata"7. Realizacja funkcji wychowawczej Kościoła ma nieść pomoc wierzącym w realizowaniu powołania chrześcijańskiego w światowych uwarunkowaniach, tak by każdy zachował swą godność chrześcijańską, nie rezygnując z aktywności w świecie ${ }^{8}$.

Kościół bierze udział w rozwoju i upowszechnianiu zasad wychowania chrześcijańskiego, aby wypełnić nakaz głoszenia misterium zbawienia wszystkim ludziom i odnawiania wszystkiego w Chrystusie. Spełnienie tej misji wymaga troski o całe życie ludzkie, również o życie ziemskie, o ile łączy się ono z niebieskim powołaniem ${ }^{9}$, Kościół jako matka jest

Zob. VC 96.

VC 96.

Paweł VI, Enc. Ecclesiam suam, 6 VIII 1964, nr 62 [dalej: ES].

8 Por. J. Przybyłowski, Funkcja wychowawcza Kościoła w kontekście nowej ewangelizacji, ,Warszawskie Studia Pastoralne UKSW” 17 (2012), s. 67.

9 II Sobór Watykański, Wstęp, w: Deklaracja o wychowaniu chrześcijańskim Gravissimum educationis [dalej: GE]. 
więc zobowiązany zapewnić tym swoim dzieciom takie wychowanie, które przepełniłoby ich całe życie duchem Chrystusowym. Jednocześnie okazuje wszystkim narodom swoją pomoc w zdobywaniu pełnej doskonałości ludzkiej, a także w tworzeniu dobra ziemskiej społeczności i w budowaniu bardziej ludzkiego świata" ${ }^{10}$ W wypełnianiu tej funkcji Kościól musi starać się robić zawsze krok do przodu, aby umiejętnie połączyć myśl Bożą z myślą ludzką, stosując język właściwy ludziom czasów współczesnych, aby prawdy Boże w miarę możności przybliżyć do ich życia i mentalności. Działalność wychowawcza ma pomóc chrześcijanom w tym, aby wiara wpływała na ich sposób myślenia, na słowa, myśli, obyczaje, poglądy, zwłaszcza wtedy gdy przeżywają duchowe trudności ${ }^{11}$. Dlatego też ojcowie Soboru polecili, by podstawowe zasady wychowania chrześcijańskiego, szczególnie szkolnego, zostały rozwinięte szerzej przez specjalną komisję i dostosowane przez konferencje biskupów do różnorodnych warunków regionalnych ${ }^{12}$.

To rozwijanie i dostosowywanie nauczania Kościoła dokonuje się według zasady ciaggłości i zmiany, która zakłada wierność katolickiej tożsamości i podstawom oraz zmiany adaptacyjne w dziedzinie praktyki wychowawczej. Wskazuje się, iż, wielu wiernych opacznie sądzi, że odnowa Kościoła polega przede wszystkim na dostosowaniu swoich poglądów i obyczajów do obyczajów świeckich i skłonności tego świata"13. Tym bardziej zatem należy przyjąć jako główną zasadę w wypełnianiu funkcji wychowawczej Kościoła pouczenie Chrystusa, że Jego uczniowie powinni być na świecie, ale nie z tego świata. Kościól, mimo iż współcześnie trudno jest to pouczenie realizować w praktyce, jest do tego przygotowany, ale pod warunkiem, że nienaruszona pozostanie jego postać nadprzyrodzona i zachowane będą rysy Kościoła, nadane mu przez Chrystusa ${ }^{14}$.

W soborowej deklaracji o wychowaniu chrześcijańskim wskazano, że

wszyscy ludzie, bez względu na rasę, pochodzenie społeczne i wiek, jako cieszący się godnością osoby, posiadają nienaruszalne prawo do

10 GE 3.

11 Zob. J. Przybyłowski, Funkcja wychowawcza Kościoła w kontekście nowej ewangelizacji, dz. cyt., s. 69.

12 GE, Wstęp.

13 J. Przybyłowski, Funkcja wychowawcza Kościoła w kontekście nowej ewangelizacji, dz. cyt., s. 72.

14 Zob. J. Przybyłowski, Funkcja wychowawcza Kościoła w kontekście nowej ewangelizacji, dz. cyt., s. 73. 
wychowania odpowiadającego ich własnemu celowi [...]. Prawdziwe zaś wychowanie dąży do kształtowania osoby ludzkiej, mając na uwadze jej cel ostateczny i jednocześnie dobro społeczeństw, których członkiem jest człowiek i w których obowiązkach będzie on uczestniczył, gdy dorośnie ${ }^{15}$.

Zostało podkreślone prawo dzieci i młodzieży do otrzymywania wskazań, które pozwolą im oceniać wartości moralne według prawego sumienia, przyjmować te wartości przez osobisty wybór, jak i pełniej poznawać i miłować Boga. Katolików natomiast Kościół zachęca do wspaniałomyślnej pracy w zakresie powszechnego wychowania, aby pełne i dobroczynne współdziałanie w wychowaniu i nauczaniu zapewnić wszystkim ludziom na całym świecie ${ }^{16}$.

W wychowaniu katolickim obowiązek rodziców wychowania dzieci wyklucza zastępstwo i jest niezbywalny, dlatego nie może być calkowicie przekazany innym ani przez innych zawłaszczony ${ }^{17}$. Rodzice, ponieważ dali dzieciom życie, mają bardzo poważny obowiązek i prawo ich wychowania. Dlatego należy ich uważać za pierwszych i najlepszych wychowawców. Do chrześcijańskich rodziców przede wszystkim należy troska o chrześcijańskie wychowanie dzieci, zgodnie z nauką przekazywaną przez Kościół. Obowiązek wychowywania, chociaż ciąży przede wszystkim na rodzinie, wymaga pomocy całego społeczeństwa i dopełnienia dzieła wychowania zgodnie z zasadą pomocniczości, jednak z uwzględnieniem życzeń rodziców, co jest także obowiązkiem Kościoła. W tym celu Kościół zakłada własne szkoły i instytucje, jeśli wymaga tego dobro wspólne ${ }^{18}$.

Kościół zabiega o wszystkie odpowiednie środki do wypełnienia swej funkcji wychowawczej, stosując przede wszystkim środki sobie właściwe. Najważniejszym z nich jest katechizacja dzieci, młodzieży i dorosłych. W Dyrektorium katechetycznym określającym zasady chrześcijańskiego wychowania dzieci i młodzieży, które obecnie realizuje się w środowisku szkolnym, uwzględnia się pełny kontekst. Prawdziwym wyzwaniem jest nie tylko dążenie do zagwarantowania rodzinie pierwszoplanowej roli w wychowaniu, także w wychowaniu

\footnotetext{
GE.

Zob. GE.

Kodeks prawa kanonicznego, kan. $226 \rrbracket 2$.

Zob. GE.
} 
religijnym, ale również przychodzenie jej z pomocą. Chodzi o to, aby rodzina była dzisiaj w stanie stawać się prawdziwą wspólnotą wychowującą i ewangelizującą, w której rozwijane będą wychowawcze zasady czerpiące swą siłę z żywego kontaktu z Bogiem, z Ewangelii, z ofiarnej i bezinteresownej miłości, roztropnie stawiającej także konieczne wymagania. Działania takie są potrzebne i poniekąd konieczne, ponieważ wiele wspólnot małżeńskich i rodzinnych przeżywa różnorodne trudności, którym same nie mogą sprostać ${ }^{19}$.

Katecheza jako część procesu ewangelizacji jest zarówno ksztalceniem, wychowaniem, jak i wtajemniczeniem. Konieczne jest takie jej przystosowanie, aby został wypełniony postulat Kościoła o komplementarności szkolnego nauczania religii i katechezy parafialnej. Jej funkcje jedynie częściowo mogą być zrealizowane w szkole, a parafia wciąż pozostaje podstawowym miejscem realizowania się katechezy.

Cele katechezy osiągane są poprzez realizację następujących jej zadań:

- rozwijanie poznania wiary,

- wychowanie liturgiczne,

- formacja moralna,

- nauczanie modlitwy,

- wychowanie do życia wspólnotowego,

- wprowadzenie do misji ${ }^{20}$.

Ważnym miejscem katechezy dzieci i młodzieży są zespoły liturgiczne, a programy pracy z ministrantami powinny również przygotowywać intelektualnie i duchowo do przeżywania i rozumienia obrzędów, w których pełnią służbę ${ }^{21}$. Ważny nurt katechezy parafialnej dzieci i młodzieży stanowią ruchy i stowarzyszenia katolickie, duszpasterstwo harcerzy, pielgrzymki i wyjazdy wakacyjne. Należy troszczyć się o to, aby na spotkaniach nigdy nie brakowało elementów religijnych i kontynuowana była praca nad kształtowaniem własnego charakteru. Katecheza winna zachęcać do uczestnictwa w liturgii i nabożeństwach maryjnych ${ }^{22}$.

Kościół w sposób szczególny zachęca osoby zakonne do podejmowania pracy katechetycznej. Wzywa, aby - uwzględniając charyzmat

19 Zob. Konferencja Episkopatu Polski, Dyrektorium katechetyczne Kościota katolickiego w Polsce, Warszawa 2001, nr 9 [dalej: DE].

20 Zob. Kongregacja ds. Duchowieństwa, Dyrektorium ogólne o katechizacji, Poznań 1998, nry 86-87.

21 Zob. DE 110.

$160 \quad 22$ Zob. DE nr 83. 
własnego zgromadzenia - jak najpilniej przygotowywały się do zadań katechetycznych i poświęcały maksimum zdolności i możliwości zaszczytnemu dziełu katechizacji ${ }^{23}$. Ich oryginalny i szczególny udział w działalności katechetycznej, który wynika z publicznego świadectwa ich konsekracji, nie może być zastąpiony ani przez kapłanów, ani przez świeckich. Wiele też zgromadzeń zakonnych powstało po to, by realizować misję głoszenia słowa Bożego, co czynią także, troszcząc się o chorych i ubogich, i w swoisty dla siebie sposób uczestniczą w dziele ewangelizacji. W działalności katechetycznej charyzmaty różnych wspólnot zakonnych nadają jej własną specyfikę oraz wielką głębię religijną, społeczną i pedagogiczną, dlatego powinny zachować nienaruszony własny charakter katechezy ${ }^{24}$.

Kościół zachęca wspólnoty zakonne, aby podejmując się różnych dzieł na rzecz młodziė̇y, zwłaszcza najbardziej opuszczonej, wprowadzały do niej, gdzie tylko to możliwe, elementy katechezy ${ }^{25}$. Podejmują one także w przedszkolach i szkole publicznej nauczanie religii, którego zadaniem jest wychowanie chrześcijańskie i przekaz nauki wiary, tak by doprowadzić do umiłowania Boga i przylgnięcia do $\mathrm{Niego}^{26}$.

Spośród wszystkich środków pomocniczych wychowania szczególne znaczenie ma szkoła, ponieważ mocą swego posłannictwa wytrwale i troskliwie kształtuje władze umysłowe, rozwija zdolność wydawania prawidłowych sądów, wprowadza w dziedzictwo kultury wytworzonej przez minione pokolenia, kształci poczucie wartości, przygotowuje do życia zawodowego, a tworząc warunki do przyjaznego współżycia wychowanków różniących się charakterem i pochodzeniem, kształtuje postawy wzajemnego rozumienia ${ }^{27}$.

Kościól, traktując wychowanie jako dzieło, w którym jest miejsce na współpracę rodziców z innymi podmiotami społecznymi, i świadom ogromnego obowiązku uważnej troski o moralne i religijne wychowanie wszystkich swych dzieci, zakłada szkoły katolickie i zarządza nimi, uwzględniając potrzeby współczesności. Kapłanów, zakonników i świeckich, którzy z ewangelicznym oddaniem poświęcają się zaszczytnej pracy wychowawczej i szkolnej każdego rodzaju

\footnotetext{
Zob. Jan Paweł II, Adh. apost. Catechesi tradendae, nr 65

Zob. DE 228-229.

Zob. DE 131.

Zob. DE 83.

Zob. GE 5.
} 
i stopnia, wspomaga i zachęca ich do szlachetnej wytrwałości w wykonywaniu podjętego zadania ${ }^{28}$.

\section{Uwarunkowania realizacji funkcji wychowawczej Kościoła w diecezji tarnowskiej}

Wypełnianie funkcji wychowawczej koniecznie wymaga otwarcia Kościoła na świat, a przede wszystkim na rodzinę i człowieka. Wychowanie jako najważniejsze zadanie uzupełniające i wspierające realizację misji zbawczej wymaga współpracy wszystkich członków Kościoła, by odpowiedzieć na nurtujące ich pytania i wspierać właściwie rodzinę w pełnieniu jej funkcji wychowawczej. Wychowanie katolickie domaga się integralnego i harmonijnego rozwoju osoby ludzkiej. W procesie tym tak samo ważne jest zdobywanie wiedzy, kształtowanie godności, formacji duchowej, kształtowanie postaw społecznych, rozwijanie umiejętności oraz świadomej i praktycznej realizacji zadań. Właściwą podstawą działań wychowawczych jest uwzględnianie pełnego kontekstu tradycji praktyki pedagogicznej, jej społeczno-kulturowych i religijno-moralnych uwarunkowań i wprowadzenia zasad wychowania integralnego ${ }^{29}$. Dlatego bardzo ważne jest również uwzględnianie specyfiki regionalnej we wszystkich tych aspektach.

Według badań postaw społeczno-religijnych Polaków diecezja tarnowska należy w Polsce do szczególnych z racji wysokich wskaźników życia religijnego. Ma największą liczbę księży, alumnów w seminariach, najgęstszą sieć parafialną i od lat charakteryzuje się najwyższymi wskaźnikami uczestnictwa w niedzielnych mszach św. - dominicantes. Należy ona również do diecezji najsłabiej (po zamojskiej) zurbanizowanych. Te wysokie wskaźniki praktyk religijnych i powołań mogą mieć związek ze strukturą życia rodzinnego, gdyż bardzo częste są na tym terenie rodziny wielopokoleniowe i wielodzietne. Duże znaczenie ma również przywiązanie do tradycyjnych obyczajów i form życia religijnego, szczególnie odpustów, pielgrzymek, nabożeństw maryjnych i pokutnych. Wciąż zwraca uwage doniosłość społecznej

28 Benedykt XVI, Przemówienie do wiernych diecezji rzymskiej z okazji przekazania im Listu o pilnej potrzebie wychowania, Rzym, 23 lutego 2008.

29 Zob. J. Przybyłowski, Funkcja wychowawcza $w$ teorii i praktyce eklezjalnej. Studium teologiczno-pastoralne, Warszawa 2010, s. 17-21. 
roli księdza w środowisku lokalnym i duże zaangażowanie diecezjan w pomoc misjom. Na terenie diecezji działa 38 zgromadzeń żeńskich (w tym 3 klauzurowe) i 2 świeckie instytuty życia konsekrowanego w ok. 140 domach ${ }^{30}$, w których przebywa ok. 980 sióstr $^{31}$, i 16 zgromadzeń męskich w ok. 25 domach ${ }^{32}$. Można na tej podstawie stwierdzić, że realizacja misji wychowawczej znajduje sprzyjające warunki, ale także stawia duże wymagania pod względem umiejętnego pełnienia funkcji pedagogicznych w imieniu Kościoła, w której teoria z praktyką nawzajem się przenikają.

3. Formy zaangażowania zgromadzeń zakonnych na polu edukacji na przykładzie wybranych rodzin zakonnych diecezji tarnowskiej

3.1. Działalność wychowawczo-katechetyczna osób konsekrowanych w diecezji tarnowskiej

Osoby konsekrowane w diecezji tarnowskiej realizują wielorakie formy pracy wychowawczej w placówkach zarówno własnych, jak i publicznych. Dominującą formą zaangażowania w realizację funkcji wychowawczej Kościoła jest nauczanie i wychowywanie poprzez pracę katechetyczną. Nie ogranicza się ona jednak tylko do zajęć dydaktycznych w szkole, ale obejmuje także podejmowanie innych inicjatyw na rzecz dzieci, młodzieży i ich rodzin. Wiąże się ze ścisłą współpracą z parafią, prowadzeniem różnych grup formacyjnych, jak koła lub ogniska misyjne, biblijne, różańcowe, charytatywne, teatralne, chóry czy schole i inne. Obejmuje organizowanie wakacji i ferii zimowych dla dzieci i młodzieży, szczególnie ze środowisk ubogich materialnie oraz o niskim statusie społecznym i moralnym.

Możemy zobrazować tę posługę osób konsekrowanych na przykładzie 15 zgromadzeń żeńskich, które odpowiedziały na zaproponowaną ankietę, ujmując posługę 88 domów zakonnych we własnych dziełach i przy parafiach. Są to następujące zgromadzenia:

30 Zob. www.zakony.diecezja.tarnow.pl/index_01.php?z=k (dostęp 28.08.2015).

31 Instytut Statystyki Kościoła Katolickiego (ISKK), Kościót katolicki w Polsce 1991-2011. Rocznik statystyczny, Warszawa 2014, s. 131.

32 Zob. www.zakony.diecezja.tarnow.pl/index_01.php? $z=m$ (dostęp 28.08.2015). 
albertynki (SAPU) - z 1 na 5 domów w diecezji, od 1963 r. dominikanki (OP) - 2 na 6 domów, od 1888 r.

józefitki (CSSJ) - 4 na 8 domów, od 1900 r.

loretanki (CSBML) - 2 na 2 domy,

niepokalanki (CSIC) - 1 na 1 dom, od 1897 r.

serafitki (CMBB) - 1 na 1 dom, od 1943 r.

sercanki (SSCJ) - 1 na 2 domy, od 1981 r.

siostry Matki Bożej z Syjonu (NDS) - 1 na 2 domy,

siostry Wspomożycielki - 1 na 1 dom, od 1969 r.

szarytki (SM) - 6 na 7 domów,

sługi Jezusa (AI) - 1 na 3 domy, od 1899 r.

służebnice Ducha Świętego (SSpS) - 1 na 1 dom, od 1985 r.

służebniczki dębickie (BDNP) - 29 na 29 domów, od 1880 r.

służebniczki starowiejskie (BDNP) - 34 na 36 domów, od 1867 r. urszulanki (USJK) - 2 na 2 domy, od 1938 r.

Brak kompletnych danych uniemożliwia ukazanie pełnego obrazu tej posługi, z uwzględnieniem liczby sióstr oraz wychowanków i dzieł. Jest to zagadnienie bardzo interesujące i warte opracowania, które może ułatwiłoby koordynację działań opiekuńczo-wychowawczych w integralnym wychowaniu i wspieraniu współczesnej rodziny i wspólnoty w dziedzinie edukacji katolickiej w diecezji. Ukazane poniżej formy i zasięg posługi sióstr zakonnych oparty jest zasadniczo na danych i informacjach przekazanych w odpowiedziach na pytania. Stanowi przykładowy obraz bogactwa podejmowanych wobec dzieci i młodzieży działań edukacyjnych i opiekuńczo-wychowawczych, wpisanych w kontekst służby rodzinom, chorym, ubogim, zgodnie z charyzmatem i duchowością własnej rodziny zakonnej.

Większość wysiłków duszpasterskich osób konsekrowanych, szczególnie sióstr zakonnych, w diecezji tarnowskiej koncentruje się wokół katechezy w przedszkolach, szkolach podstawowych, średnich i gimnazjach oraz

\begin{tabular}{|c|c|c|c|c|c|}
\hline \multirow[t]{2}{*}{ 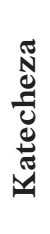 } & $\begin{array}{l}\text { Liczba } \\
\text { dzieci } \\
\text { przedszkol- } \\
\text { nych }\end{array}$ & \begin{tabular}{|l} 
Liczba \\
dzieci \\
szkolnych
\end{tabular} & $\begin{array}{l}\text { Liczba } \\
\text { młodzieży } \\
\text { gimnazjal- } \\
\text { nej }\end{array}$ & $\begin{array}{l}\text { Liczba } \\
\text { młodzieży } \\
\text { licealnej }\end{array}$ & Razem \\
\hline & 8416 & 9379 & 1645 & 3495 & 22930 \\
\hline
\end{tabular}

Siostry we współpracy z parafiami, odpowiadając na wyzwania środowiska, w którym realizują misję wychowania katolickiego dzieci 
i młodzieży zgodnie ze swoim charyzmatem, prowadzą następujące grupy formacyjne:

\begin{tabular}{|l|l|l|l|l|l|}
\hline $\begin{array}{l}\text { Wspólnota } \\
\text { lub grupa } \\
\text { formacyjna }\end{array}$ & $\begin{array}{l}\text { Liczba } \\
\text { dzieci } \\
\text { przed- } \\
\text { szkolnych }\end{array}$ & $\begin{array}{l}\text { Liczba } \\
\text { dzieci } \\
\text { szkolnych }\end{array}$ & $\begin{array}{l}\text { Liczba } \\
\text { młodzie- } \\
\text { ży gim- } \\
\text { nazjalnej }\end{array}$ & $\begin{array}{l}\text { Liczba } \\
\text { młodzieży } \\
\text { licealnej }\end{array}$ & Razem \\
\hline $\begin{array}{l}\text { Liturgiczna } \\
\text { Służba } \\
\text { Ołtarza }\end{array}$ & 30 & 10 & 40 \\
\hline $\begin{array}{l}\text { Dziewczęca } \\
\text { Służba } \\
\text { Maryjna }\end{array}$ & 4 & 2117 & 239 & 1 & 2361 \\
\hline $\begin{array}{l}\text { Dzieło } \\
\text { Misyjne } \\
\text { Dzieci }\end{array}$ & 350 & 189 & 15 & 539 \\
\hline koła Caritas & & 9 & 78 & 120 & 239 \\
\hline wolontariat & & 11 & 108 & 40 & 148 \\
\hline schola $\mid$ chór & 20 & 854 & 234 & & 102 \\
\hline
\end{tabular}

Wszystkie z omawianych zgromadzeń realizują te przyjęte w diecezji formy katechezy parafialnej, pracy apostolskiej z dziećmi i młodzieżą. Samo szkolne nauczanie religii nie wypełni w zadowalającym stopniu wszystkich założeń integralnie ujmowanej katechezy. Wychodząc z teologicznego założenia, że podmiotem katechezy jest cały Kościól, starają się dobrze zagospodarować wszystkie miejsca katechezy, od rodziny poprzez parafię, aż do szkoły. Siostry świadome, że katecheza jako część procesu ewangelizacji jest zarówno kształceniem, wychowaniem, jak i wtajemniczeniem, animują i prowadzą wiele innych specyficznych dla danego środowiska ewangelizacyjnych form wprowadzania dzieci i młodzieży do życia chrześcijańskiego i jego dojrzewania. Parafia jest szansą i miejscem na realizowanie się w niej katechezy bogatej w treści, formy, metody i środki, takiej, która odpowiada w tym względzie zaleceniom Kościoła powszechnego i potrzebom lokalnego.

Charakter, duchowość i liczebność prowadzonych grup wyraża maryjność diecezjan, ich wrażliwość na potrzeby misji i potrzeby innych, a jednocześnie rozwija je w nowych pokoleniach. W grupach DSM dokonuje się przede wszystkim formacja wewnętrzna w duchu 
maryjnym. Dziewczęta od klasy II szkoły podstawowej do gimnazjum, wpatrzone w przykład Maryi Niepokalanej, uczą się żyć i kochać tak jak Ona, postrzegać rzeczywistość w Bożym świetle. Wspólnie pogłębiają swoją wiarę poprzez modlitwę, pracę, śpiew i pogadanki tematyczne, różne formy gier i zabaw towarzyskich, które mają charakter czynnego i twórczego uczestnictwa. Uczą się wspólpracy w grupie, odpowiedzialności za siebie i innych w domu, szkole, parafii. Starają się apostołować własnym przykładem oraz rozwijać w sobie i innych nabożeństwo do Matki Bożej i zaangażowanie w apostolstwie misyjnym.

Katolickie wychowanie służące rozwijaniu ducha modlitwy realizowane jest we wspólnotach modlitewnych. Np. siostry służebniczki starowiejskie w Mikluszowicach prowadzą wspólnotę Biała Armia, do której należy 250 dzieci klas młodszych (od kl. I), przygotowujących się do sakramentów Pierwszej Spowiedzi i Pierwszej Komunii Świętej. Głównym celem Białej Armii jest troska o życie duchowe dzieci i ich wprowadzenie w celebrację najważniejszych wydarzeń roku liturgicznego oraz modlitwa dzieci za parafię, szczególnie za te osoby, które najbardziej jej potrzebują. Inną formą formacji duchowej i wspólnej modlitwy są koła Żywego Różańca, prowadzone przez siostry wspomożycielki dusz czyśćcowych (80 dzieci), służebniczki dębickie (27 osób) i służebniczki starowiejskie (297 dzieci).

Wydarzeniem ważnym dla formacji duchowej dzieci i młodzieży są rekolekcje organizowane w domach zakonnych. Np. siostry józefitki w Tarnowie organizują dni skupienia jeden raz w miesiącu oraz rekolekcje dla dziewcząt w czasie ferii i wakacji, w których uczestniczyło 70 dziewcząt ze szkoły podstawowej, 30 z gimnazjum i 20 z liceum. Siostry służebniczki starowiejskie organizują w Szynwałdzie rekolekcje młodzieżowe, w których rocznie uczestniczy od 200 do 420 dziewcząt. Zorganizowały także rekolekcje maturzystów (34 osoby) i rekolekcje wyjazdowe w Ośrodku Rekolekcyjnym „,Opoka” w Starym Sączu dla 160 uczniów szkoły podstawowej i gimnazjum.

Ewangelizacyjny wymiar formacji dzieci i młodzieży we wspólnocie siostry realizują w grupach i ruchach religijnych. Np. 13 sióstr służebniczek starowiejskich w dniach 13-15 czerwca 2014 roku z grupą ok. 370 dzieci włączyło się w II Saletyńskie Dni Dzieci zorganizowane w Sanktuarium Pana Jezusa Ukrzyżowanego w Kobylance k. Gorlic, a 12-14 czerwca 2015 roku uczestniczyly z grupą 150 dzieci w III Saletyńskich Dniach Dzieci. Także w Saletyńskie Dni Młodych zaangażowały 86 osób spośród młodzieży licealnej. Prowadzą również grupę 166 Oaza - Ruch Światło-Życie (17 gimnazalistów). Siostry dominikanki 
prowadzą grupę młodzieżową Effata dla 30 osób, siostry urszulanki SJK - Eucharystyczny Ruch Młodych (36 osób), służebniczki dębickie - wspólnoty Rodzina bł. Edmunda Bojanowskiego dla 413 dzieci i młodzieży, Pomocnicy Maryi (120 osób) oraz Ruch Czystych Serc (38 osób), służebniczki starowiejskie - Koła Biblijne (39 osób).

Działalność wychowawczo-katechetyczna osób konsekrowanych w diecezji tarnowskiej w przedszkolach i szkołach wiąże się dzisiaj z różnorakimi trudnościami, wymaga rozwijania ducha wiary, poświęcenia i zapału apostolskiego. Wydział katechetyczny wspomaga zatem katechetów wielorako, organizując spotkania formacyjne i organizacyjne, dając nie tylko wytyczne, ale i duży wybór pomocy przydatnych w duszpasterstwie dzieci i młodzieży w diecezji tarnowskiej. Siostry potrzebują także wsparcia w ich pracy z rodzicami, by mogły im uświadamiać ich rolę w procesie religijnego wychowania dzieci. Obecność sióstr w szkole, zwykle bardzo ceniona przez grono pedagogiczne, staje się okazją do dawania świadectwa wiary w środowisku szkolnym.

Różnorodność form katechezy parafialnej prowadzonej przez osoby konsekrowane jest wyrazem bogactwa ich charyzmatów, a jednocześnie sposobem realizacji wezwania:

A wy, drodzy kapłani, zakonnicy i zakonnice, katecheci, animatorzy i wychowawcy działający w parafiach, opiekunowie grup młodzieżowych, stowarzyszeń i ruchów kościelnych, oratoriów, organizatorzy działalności sportowej i rekreacyjnej, starajcie się zawsze żywić do dzieci i młodzieży, z którymi macie do czynienia, te same uczucia, które były w Jezusie Chrystusie. Bądźcie więc dla nich godnymi zaufania przyjaciółmi, dzięki którym będą mogli namacalnie doświadczyć przyjaźni Jezusa względem nich, a jednocześnie bądźcie też szczerymi i odważnymi świadkami owej prawdy, która wyzwala i która wskazuje nowym pokoleniom droge prowadzącą do życia. Jednak wychowanie nie jest tylko dziełem wychowawców: jest to relacja między osobami, w której, w miarę dorastania, coraz większą rolę odgrywa wolność i odpowiedzialność wychowanków ${ }^{33}$.

Dyrektorium katechetyczne Kościoła katolickiego w Polsce oraz przyjęta przez Konferencję Episkopatu Polski Podstawa programowa katechezy

33 Benedykt XVI, Przemówienie do wiernych diecezji rzymskiej z okazji przekazania im Listu o pilnej potrzebie wychowania, Rzym, 23 lutego 2008. 
Kościoła w Polsce gwarantują katechezie w Polsce podstawową jednolitość. Na tej podstawie katecheza szkolna i parafialna jest prowadzona przez wszystkich katechetów - księży, osoby konsekrowane i świeckich.

\subsection{Działalność edukacyjna prowadzona}

przez wybrane zgromadzenia zakonne w diecezji tarnowskiej

W celu realizacji wychowawczej funkcji zgodnie $z$ nauczaniem Kościoła osoby konsekrowane pracują także w placówkach edukacyjnych prowadzonych w całości przez dane zgromadzenie, takich jak: przedszkola, szkoły, ośrodki wychowawcze, internaty. Przykładem są dane wybranych zgromadzeń:

\begin{tabular}{|c|c|c|c|c|c|}
\hline \begin{tabular}{|l} 
Placówka \\
prowadzona \\
przez \\
zgromadzenie
\end{tabular} & $\begin{array}{l}\text { Liczba } \\
\text { dzieci } \\
\text { przed- } \\
\text { szkol- } \\
\text { nych }\end{array}$ & $\begin{array}{l}\text { Liczba } \\
\text { dzieci } \\
\text { szkolnych }\end{array}$ & $\begin{array}{l}\text { Liczba } \\
\text { mło- } \\
\text { dzieży } \\
\text { gimna- } \\
\text { zjalnej }\end{array}$ & $\begin{array}{l}\text { Liczba } \\
\text { młodzie- } \\
\text { ży } \\
\text { licealnej }\end{array}$ & Razem \\
\hline $\begin{array}{l}\text { Przedszkole } \\
\text { - siostry (ok. 90): } \\
\text { niepokalanki - 1 } \\
\text { serafitki - 1 } \\
\text { szarytki - 1 } \\
\text { józefitki - } 4 \\
\text { służebniczki } \\
\text { dębickie - } 12 \\
\text { służebniczki } \\
\text { starowiejskie - } 18\end{array}$ & $\begin{array}{l}1670 \\
115 \\
53 \\
42 \\
158 \\
484 \\
818\end{array}$ & & & & 1670 \\
\hline $\begin{array}{l}\text { Szkoła: } 5 \text { sióstr } \\
\text { Technikum } \\
\text { Gastronomiczno- } \\
\text {-Hotelarskie } \\
\text { i Zasadnicza } \\
\text { Szkoła } \\
\text { Gastronomiczna } \\
\text { Sióstr } \\
\text { Niepokalanek } \\
\text { im. Królowej } \\
\text { Polski }\end{array}$ & & & & 63 & 63 \\
\hline
\end{tabular}




\begin{tabular}{|c|c|c|c|c|c|}
\hline $\begin{array}{l}\text { Placówka } \\
\text { prowadzona } \\
\text { przez } \\
\text { zgromadzenie }\end{array}$ & $\begin{array}{l}\text { Liczba } \\
\text { dzieci } \\
\text { przed- } \\
\text { szkol- } \\
\text { nych }\end{array}$ & $\begin{array}{l}\text { Liczba } \\
\text { dzieci } \\
\text { szkolnych }\end{array}$ & $\begin{array}{l}\text { Liczba } \\
\text { mło- } \\
\text { dzieży } \\
\text { gimna- } \\
\text { zjalnej }\end{array}$ & $\begin{array}{l}\text { Liczba } \\
\text { młodzie- } \\
\text { ży } \\
\text { licealnej }\end{array}$ & Razem \\
\hline $\begin{array}{l}\text { Placówka poza- } \\
\text { szkolna/świetlica } \\
\text { siostry (11): } \\
\text { służebnice Ducha } \\
\text { Świętego - } 1 \\
\text { służebniczki } \\
\text { dębickie - } 3 \\
\text { szarytki - } 1 \\
\text { albertynki - } 1\end{array}$ & & $\begin{array}{l}15 \\
153 \\
50 \\
30\end{array}$ & & & 248 \\
\hline $\begin{array}{l}\text { Bursa Szkolna dla } \\
\text { Dziewcząt w Tar- } \\
\text { nowie - prowa- } \\
\text { dzona przez Slugi } \\
\text { Jezusa (8 sióstr) }\end{array}$ & & & & 58 & 58 \\
\hline
\end{tabular}

Dzieła prowadzone przez poszczególne zgromadzenia zakonne i realizacja ich funkcji wychowawczej dokonuje się zgodnie z ich charyzmatem, zatwierdzonym przez Kościól. Jan Paweł II ukazał istotę tych dzieł:

Cały Kościół jest ożywiany przez Ducha i wraz z Nim prowadzi swoje dzieło wychowywania. Jednakże w łonie Kościoła szczególne zadanie w tej dziedzinie mają do spełnienia osoby konsekrowane, które są powołane, aby na polu wychowawczym dawać radykalne świadectwo o dobrach Królestwa, dostępnych dla każdego człowieka oczekującego na ostateczne spotkanie z Panem historii. Dzięki swojej specjalnej konsekracji, szczególnemu doświadczeniu darów Ducha Świętego, gorliwemu wsłuchiwaniu się w słowo Boże i praktyce rozeznawania, dzięki bogatemu dziedzictwu tradycji wychowawczych, zgromadzonemu przez cały Instytut, oraz dzięki głębokiemu poznaniu duchowej prawdy (por. Ef 1,17 ) osoby konsekrowane są w stanie prowadzić szczególnie owocną działalność edukacyjną, wnosząc ważny wkład w pracę innych wychowawców ${ }^{34}$. 
Praca wychowawcza w poszczególnych placówkach i realizowane programy są zgodne z obowiązującymi podstawami prawnymi i ubogacone specyfiką misji zgromadzenia.

\subsubsection{Przedszkola prowadzone w diecezji tarnowskiej}

Przedszkola prowadzone w naszej diecezji przez siostry to katolickie placówki publiczne i niepubliczne, wiele z nich ma charakter integracyjny, otwarty na dzieci niepełnosprawne. We wszystkich realizowane jest wychowanie integralne, by „objąć pełną formację osoby ludzkiej w odniesieniu zarówno do celu ostatecznego, jak i do dobra wspólnego społeczności, dlatego dzieci winny być tak wychowywane, ażeby mogły rozwijać harmonijnie swoje przymioty fizyczne, moralne oraz intelektualne, zdobywać coraz doskonalszy zmysł odpowiedzialności, właściwie korzystać z wolności i przygotowywać się do czynnego udziału w życiu społecznym"35.

Najwięcej, bo 30 przedszkoli - ochronek prowadzonych jest przez siostry służebniczki starowiejskie i dębickie jako placówki z właściwą sobie specyfiką, która wynika z misji i posłannictwa zgromadzenia sióstr służebniczek określonych przez jego założyciela, bł. Edmunda Bojanowskiego. Ochrona jako instytucja, która wyrosła z potrzeb społecznych, jest przede wszystkim miejscem wychowywania dzieci. Służy ochranianiu osoby i wartości przez szanowanie i zachowywanie tradycji rodzinnych, religijnych i narodowych, przekazywanie ich $\mathrm{w}$ procesie integralnego wychowania dziecka i wsparcie rodziny dla moralnego odradzania i zachowania tożsamości narodu. Działania, które podejmują siostry w poczuciu misji służby człowiekowi, zmierzają do ochrony godności osoby wychowanka poprzez odkrywanie i rozwijanie jego darów nadprzyrodzonych i naturalnych w odniesieniu do rzeczywistości, w jakiej żyje i do jakiej zmierza. Zakres oddziaływań wychowawczych przekracza wymiar jedynie widzialny, rozszerzając się na wymiar łaski i transcendencji, w tym także na ideały i wartości związane z życiem codziennym, a dotykające tajemnicy świętych obcowania i nadprzyrodzoności. Bł. Edmund Bojanowski odnosił się do prawdy, że do rodziców należy podstawowy i niezbywalny obowiązek oraz prawo wychowywania dzieci. Uważał, że wychowanie jest głównym powołaniem kobiety, która jest „osią koła

35 KPK, kan. 795. 
rodzinnego" "36. Siostry, realizując w swej pracy pedagogicznej założenia integralnej pedagogiki przedszkolnej Bojanowskiego, czerpią motywację, znajdują zasady i sposoby dobrej wspólpracy z rodzicami w rzetelnej wiedzy i formacji chrześcijańskiej ${ }^{37}$. Właściwie zorganizowana wspólpraca obu środowisk wychowawczych w przekazie systemu norm i wartości, integralnym rozwoju i wychowaniu dziecka jest oparta na jasno określonych zasadach.

Siostry józefitki realizują misję wychowawczą w swoich przedszkolach, wspierając dzieci we wszechstronnym rozwoju w oparciu o wartości chrześcijańskie i towarzysząc im w odkrywaniu piękna stworzonego świata i jego Stwórcy. Starają się przekazać dzieciom radość plynącą z Ewangelii poprzez wychowanie i rozwijanie w nich postaw prospołecznych, zgodnie z przykazaniem miłości Boga i bliźniego. Wspierają rodzinę w wychowaniu dzieci i kształtowaniu w nich właściwego „stanowiska wobec Boga, Kościoła i państwa” na wzór św. ks. Zygmunta Gorazdowskiego, stając się ,,wszystkim dla wszystkich, aby zbawić choć jednego". Tak organizują przedszkole, by stawało się miejscem i środowiskiem, w którym dziecko jest szczęśliwe, może rozwijać się i wzrastać w poczuciu bezpieczeństwa, atmosferze miłości, akceptacji i szacunku. Czynią to zgodnie ze wskazaniami św. ks. Zygmunta Gorazdowskiego, który mówił: „Społeczeństwo składa się z jednostek, a kto szczerze pragnie dobra dla ogólu, musi przede wszystkim korzystnie i zbawiennie wplywać na poszczególne jednostki, które mu Pan Bóg powierzył. Jak te jednostki dzisiaj wychowamy, takim będzie całe społeczeństwo za lat kilkadziesiąt" 38 .

Jednym z podstawowych zadań, jakie siostry serafitki pełnią w Kościele, jest opieka nad dziećmi. Czynią to według wskazania bł. o. Honorata Koźmińskiego: „Główną ustawą i jakby zasadą Córek Boleści Matki Bożej jest to, że się poświęcają na usługę dziatek i ubogich - służąc w nich Chrystusowi". Wierne swojemu charyzmatowi, siostry serafitki już od pierwszych lat swego istnienia prowadzą ochronki dla dzieci w wieku przedszkolnym. Troską a zarazem zadaniem ich przedszkoli jest pomoc rodzicom w wychowaniu i sprawowaniu opieki nad dzieckiem. Respektując prawdę, iż to rodzice są pierwszymi wychowawcami

36 Archiwum Główne Służebniczek Dębickich w Dębicy (AGSD), Notatki Edmunda Bojanowskiego (B); AGSD, B- i-1, k. 11r.

37 M. Opiela, Integralna pedagogika przedszkolna $w$ systemie wychowania Edmunda Bojanowskiego. Kontynuacja i zmiana, Lublin 2013, s. 304.

38 www.przedszkole-tuchow.jozefitki.pl/koncepcja.html (dostęp 28.08.2015). 
swoich dzieci, działalność wychowawczo-dydaktyczną realizują w ścisłej współpracy z rodzicami dziecka. Tak spełniają w stosunku do nich funkcję doradczą i wspierającą w pełnieniu roli wychowawczej. Siostry i współpracujące z nimi osoby świeckie wraz z rodzicami dążą do ujednolicenia kierunku oddziaływań wychowawczych, co jest jednym z koniecznych warunków prowadzenia pracy wychowawczo-dydaktycznej ${ }^{39}$.

\subsubsection{Szkoły prowadzone przez zgromadzenia zakonne w diecezji tarnowskiej}

Najbardziej znana w diecezji tarnowskiej jest placówka sióstr niepokalanek w Nowym Sączu. Od 1897 roku siostry prowadzą tu szkołę, która przechodziła różne przeobrażenia w związku z zachodzącymi przemianami społeczno-politycznymi i oświatowymi w naszej ojczyźnie, począwszy od szkółki ludowej na początku, po technikum obecnie. Od roku 2011 działa przedszkole - w ostatnim roku było około 115 dzieci. Mimo różnorakich zmian organizacyjnych niezmiennymi pozostają podstawy i założenia, na których m. Marcelina Darowska zbudowała system wychowawczy i zasady wskazane przez nią do pracy edukacyjnej. Specyfiką pracy zgromadzenia jest bowiem wychowanie, a drogą na jakiej starają się je realizować jest edukacja dzieci i młodzieży, w szczególności dziewcząt.

Aktualnie działają Technikum Gastronomiczno-Hotelarskie (37 uczennic) i Zasadnicza Szkoła Gastronomiczna Sióstr Niepokalanek im. Królowej Polski (26 uczennice). Przy szkołach działa internat. We wrześniu 2015 roku ruszyła I klasa szkoły podstawowej. W szkołach przy stosunkowo wysokim poziomie kształcenia prymat zawsze ma wychowanie, które ma doprowadzić do ukształtowania człowieka na obraz Boży. Uczennice są prowadzone do samowychowania i stopniowo, w miarę zbliżania się do dorosłości, są angażowane w wychowywanie młodszych koleżanek.

W pracy apostolskiej siostry starają się czerpać z bogatej spuścizny pozostawionej zgromadzeniu przez bł. Matkę Marcelinę Darowską. Jej słowa skierowane do sióstr nie tylko się nie zdezaktualizowały, ale w miarę upływu czasu nabierają nowego znaczenia:

Świat jest odbiciem rodziny - cały jej upadek uwydatnia się w smutnym stanie dzisiejszego świata i woła: naprawy, dźwignięcia, świętości! 
Teraźniejsze skarłowacenie świata z tego pochodzi, że upadła rodzina: charakter jej zmalał, duch zagasł, niepojęta jest, nieuszanowana. Waszą rzeczą dźwignąć ją, podnieść, postawić na właściwym stanowisku. To wasze zadanie. Wychowujemy do świata i dla rodziny. Podnieśmy rodzinę wychowaniem jej dzieci, przygotowaniem Ojczyźnie naszej chrześcijańskich żon i matek ${ }^{40}$.

Dziś praca wychowawcza mająca na celu odrodzenie ojczyzny, wolnej terytorialnie, ale bardzo potrzebującej odnowy moralnej i religijnej, jest wciąż aktualna ${ }^{41}$.

W realizację misji Kościoła poprzez działalność edukacyjną w sposób integralny wpisuje się system wychowawczy stworzony przez bł. Matkę Marcelinę. Jest on oparty na czterech zasadach:

1. Bóg wszystkim, przez wszystko do Boga.

2. Bóg nas stworzył Polakami.

3. Wierność obowiązkom stanu.

4. Nauczyć dzieci myśleć ${ }^{42}$.

Oparty na tych zasadach proces edukacji służy integralnemu rozwojowi i wychowaniu dzieci i młodzieży, przede wszystkim żeńskiej. Organizowany jest on w formie ośrodka wielofunkcyjnego, który zapewnia integralne wsparcie dla wychowanków.

Praca wychowawcza nie kończy się jednak wraz z ukończeniem przez dziewczęta szkoły. Absolwentki utrzymują ze zgromadzeniem żywy kontakt, spotykając się w murach szkoły na tzw „leciach matury" (5-, 10-lecie itd.). Istnieje też stowarzyszenie wychowanek szkół niepokalańskich: Koleżeńskie Zjednoczenie Jazłowieckie (KZJ). Organizowane są rekolekcje dla wychowanek. W okolicach Bożego Narodzenia i Wielkanocy organizowane jest spotkanie z wychowankami - przyjeżdża kilkadziesiąt osób.

Pracę wychowawczą siostry rozumieją jako towarzyszenie kobiecie w jej drodze. Piszą do wychowanek dziesiątki listów, odwiedzają chore wychowanki. Dla potrzebujących KZJ organizuje pomoc. Ponadto od kilku lat organizowane są w klasztorze Rekolekcje dla Zabieganych Kobiet.

Podobnie integralny charakter wychowania i organizacji działalności edukacyjnej posiada Jezuickie Centrum Edukacji w Nowym Sączu.

\footnotetext{
http://szkola.bialyklasztor.pl/content/mmarcelina (dostęp 28.08.2015).

www.szkola.bialyklasztor.pl/content/mmarcelina (dostęp 28.08.2015).

www.szkola.bialyklasztor.pl/content/zasady-wychowawcze (dostęp 28.08.2015).
} 
W jego skład wchodzą szkoły niepubliczne o uprawnieniach szkoły publicznej: Ogólnokształcące Liceum Jezuitów i Gimnazjum Jezuitów. Oprócz tego w skład Centrum wchodzi Niepubliczne Przedszkole Carissimus, które jest placówką katolicką i pracuje zgodnie z obowiązującą podstawą programową wychowania przedszkolnego. Właścicielem i osobą prowadzącą przedszkole jest Prowincja Polski Południowej Towarzystwa Jezusowego w Krakowie. Na zasadach pierwszeństwa z przedszkola korzystają dzieci nauczycieli gimnazjum i liceum w Jezuickim Centrum Edukacji.

Księża jezuici sprawują opiekę nad bursą dla młodzieży męskiej szkół gimnazjalnych i ponadgimnazjalnych (Bursa ZMMPiR). Została ona powołana do istnienia w 1991 roku przez prowincjała jezuitów w Krakowie i jest katolicką placówką opiekuńczo-wychowawczą uczącej się poza domem rodzinnym młodzieży w gimnazjach i szkołach średnich w Nowym Sączu. Celem istnienia bursy jest towarzyszenie młodym ludziom w ich formacji edukacyjnej poprzez troskę o rozwój intelektualny, ludzki i duchowy wychowanków, poprzez spotkania indywidualne i grupowe, pomoc w nauce i stały kontakt z rodzicami, wychowawcami i pedagogami szkolnymi. Bursa wspólpracuje także z organizacjami wspomagającymi proces wychowawczy ${ }^{43}$.

\subsubsection{Inne formy zaangażowania zgromadzeń zakonnych na polu edukacji}

Istnieją jeszcze inne formy zaangażowania zgromadzeń zakonnych na polu edukacji w diecezji tarnowskiej. Nie można i nie powinno się ich oddzielać od działalności wychowawczo-katechetycznej, oświatowej i charytatywnej. Wszystkie razem w proporcjach właściwych dla charyzmatu danego zgromadzenia stanowią bogactwo i wartość integralnego podejścia do człowieka, jego pełnego rozwoju i twórczej działalności na chwałę Bożą i dla dobra wspólnego.

Przykładem edukacyjnej posługi osób konsekrowanych jest posługa we własnych lub parafialnych świetlicach i placówkach wsparcia dziennego dla dzieci, młodzieży i osób w podeszłym wieku.

W Tylmanowej siostry albertynki oprócz katechezy, DSM-u i scholi prowadzą Albertyński Ośrodek Pomocy dla Dzieci i Osób Starszych jako placówkę wsparcia dziennego. Osoby korzystające z pomocy to najczęściej dzieci z rodzin dysfunkcyjnych, dotkniętych problemem

43 www.jce.pl/new (dostęp 28.08.2015). 
alkoholowym, a także z rodzin wielodzietnych, o niskim statusie materialnym. Dzieci przychodzą do sióstr po lekcjach, korzystają z posiłku, a następnie z zajęć w świetlicy. W tym czasie odrabiają lekcje, proponowane im są gry dydaktyczne, korzystają z komputera i Internetu, podejmują różnego rodzaju prace manualne i uczestniczą w innych prowadzonych zajęciach.

Najwięcej świetlic i placówek wsparcia dziennego prowadzą służebniczki dębickie, które pracują też przy parafiach. Największy jest ośrodek integracyjny sióstr służebniczek w Dębicy.

W jego skład wchodzą: przedszkole integracyjne, świetlica profilaktyczno-terapeutyczna dla dzieci i młodzieży, hostel i ośrodek wsparcia dla rodzin dysfunkcyjnych oraz dom dziennego pobytu dla osób starszych i samotnych.

Działalność placówki „Promyki Nadziei” kierowana jest do dzieci i młodzieży oraz ich rodzin. Podopieczni mają zapewnioną opiekę dzienną, rozumianąjako wspieranie rodziny przez objęcie dziecka działaniami wychowawczymi, opiekuńczymi i edukacyjnymi realizowanymi przez placówkę w ciągu dnia. Podstawowe cele placówki to:

- Wsparcie integralnego rozwoju osobowości wychowanków oraz ich pełnej integracji społecznej, zaspokajanie istniejących potrzeb dzieci i młodzieży z terenu powiatu dębickiego, pomoc wychowankom w pokonywaniu trudności szkolnych i organizowaniu czasu wolnego.

- Przygotowywanie wychowanków do ponoszenia odpowiedzialności za własne postępowanie, uczenie samodzielności i umiejętności radzenia sobie w życiu.

- Stała praca z dzieckiem i rodziną w celu wsparcia realizacji funkcji opiekuńczo-wychowawczych rodziny, szczególnie znajdującej się w sytuacji trudnej, oraz wyrównywania szans tych rodzin i osób, ochrona rodzicielstwa.

- Zapobiegania patologiom i wykluczeniu społecznemu.

- Eliminowanie istniejących nieprawidłowości rozwojowych i zaburzeń zachowania, redukcja szkód spowodowanych dysfunkcjami rodziny i środowiska ${ }^{44}$.

Realizacja celów dokonuje się przez współpracę z rodzinami w dziele katolickiego wychowania ich dzieci, w szczególności zaś w trosce

44 Zob. Statut Placówki Wsparcia Dziennego „Promyki Nadziei” w Dębicy z dnia 7 grudnia 2012 . 
o kształtowanie odpowiedzialności w rodzinach. Poza działaniami edukacyjnymi są to: odrabianie zadań domowych, zajęcia tematyczne rozwijające wiedzę i umiejętności praktyczne wychowanków, indywidualna praca $\mathrm{z}$ wychowankami i rodziną; istotnym wymiarem pracy jest formacja duchowa, liturgiczna i moralna podopiecznych. Zadania placówki realizowane są w międzypokoleniowej rodzinie ośrodka, zróżnicowanej pod względem wieku, zdrowia, sprawności, statusu materialnego i społecznego poszczególnych osób i rodzin. Klimat stwarzany przez podopiecznych, siostry i świeckich wspólpracowników i wolontariuszy pomaga doświadczać komunii w budowanej wspólnocie i wzajemnego wsparcia na bazie wartości chrześcijańskich. Organizowanie i prowadzenie różnych form i metod pracy z dziećmi, młodzieżą i osobami dorosłymi, zmierzających do integralnego rozwoju ich osobowości w duchu katolickim oraz ich pełnej integracji społecznej, dokonuje się na podstawie wskazań pedagogicznych bł. Edmunda Bojanowskiego.

Siostry urszulanki SJK w domu w Lipnicy Murowanej - miejscowości rodzinnej założycielki - to ostatnia placówka założona przez matkę Urszulę Ledóchowską za pozwoleniem bpa Lisowskiego na osiedlenie się zgromadzenia w diecezji z 19 XI 1935 roku. Przy pomocy Związku Lipniczan osiadłych w USA zgromadzenie rozpoczęło w 1938 roku budowę domu, w którym siostry zorganizowały i prowadziły ochronkę dla 35 dzieci ludności miejscowej. Obecnie zajmują się katechizacją dzieci szkolnych i przedszkolnych, prowadzą grupy Eucharystycznego Ruchu Młodych, pomagają w pracach duszpasterskich w parafii.

W Tarnowie natomiast od 28 X 1983 roku siostry urszulanki SJK prowadzą Dom Samotnej Matki. Jest on darem beatyfikacyjnym zgromadzenia dla diecezji, w której znajduje się dom rodzinny matki Urszuli Ledóchowskiej. Siostry otaczają wszechstronną opieką i pomocą młode kobiety, które z powodu ciąży znalazły się w trudnej sytuacji życiowej i nie mogą liczyć na nikogo bliskiego. Siostry pomagają tym kobietom odnaleźć się w sytuacji, w której się znalazły, często też w przyjęciu i pokochaniu dziecka, które ma się narodzić, a gdy to nie jest możliwe - kontaktują się z ośrodkiem adopcyjnym. Ponadto siostry podejmują kontakty z rodzinami tych młodych matek, z sądami, kuratorami, z rodzinami adopcyjnymi, ośrodkami pomocy społecznej, urzędami. Utrzymują kontakty także z dawnymi mieszkankami. Wielu młodym kobietom udaje się skutecznie pomóc w ułożeniu dalszego życia. Od powstania domu z pomocy sióstr skorzystało 431 kobiet i dziewcząt. 
Zgromadzenie Sióstr Sług Jezusa prowadzi Bursę Szkolną dla Dziewcząt, z której korzysta 58 licealistek pozostających pod opieką 8 pracujących w niej sióstr. Bursa jest niepubliczną, katolicką placówką zapewniającą opiekę i wychowanie dziewczętom w okresie pobierania nauki poza miejscem stałego zamieszkania. Budynek, w którym mieści się Bursa, jest własnością Zgromadzenia Sióstr Sług Jezusa.

Siostry sługi Jezusa posługują w diecezji tarnowskiej od 1899 roku. Ich posługa wychowawcza, w której przede wszystkim swoją troską otaczają dziewczęta, mając na uwadze ich sytuację materialną, religijną i społeczną, przybierała na przestrzeni wielu lat różne formy. W latach 1945-1960 zgromadzenie prowadziło Dom Dziecka „Caritas”. W 1960 roku Dom Dziecka został przekształcony w zakład wychowawczy dla chłopców z upośledzeniem umysłowym. Po 50-letniej działalności Domu Dziecka i Specjalnego Ośrodka Wychowawczego przyszła kolejna zmiana. W 1999 roku powstała Bursa Szkolna dla Dziewcząt. Opieką i wychowaniem objęto dotychczas około 230 dziewcząt z tarnowskich szkół ponadgimnazjalnych ${ }^{45}$.

Na uwagę zasługuje także Salezjańska Placówka Opiekuńczo-Wychowawcza „Dom Bosko” w Gostwicy. Jest to całodobowa niepubliczna placówka opiekuńczo-wychowawcza typu socjalizacyjnego, przeznaczona dla 14 wychowanków. Organem prowadzącym Placówkę jest Towarzystwo Salezjańskie Inspektoria Krakowska pw. św. Jacka w Krakowie. 8 grudnia 2009 roku salezjanie otrzymali decyzję Wojewody Małopolskiego pozwalającą na prowadzenie „Domu”.

Placówka zapewnia dziecku:

- całodobową opiekę i wychowanie oraz zaspokaja jego niezbędne potrzeby, w szczególności bytowe, rozwojowe, emocjonalne, społeczne, religijne i zdrowotne;

- realizuje przygotowany we wspólpracy z asystentem rodziny plan pomocy dziecku;

- umożliwia kontakt dziecka z rodzicami i innymi bliskimi, chyba że sąd postanowi inaczej;

- podejmuje działania w celu powrotu dziecka do rodziny;

- zapewnia dziecku korzystanie z przysługujących mu świadczeń zdrowotnych oraz dostęp do kształcenia dostosowanego do jego wieku i możliwości rozwojowych.

45 Por. http://bursa-tarnow-sj.edu.pl/index.php/o-nas/historia-bursy (dostęp 28.08.2015). 
Do ośrodka przyjmowane są dzieci od ósmego roku życia. Oprócz salezjanów, którzy sprawują całodobową opiekę nad chłopcami, w ośrodku zatrudnieni są także wychowawcy świeccy. Wszyscy realizują zadania mające na celu wychowanie młodzieży na „uczciwych obywateli i dobrych chrześcijan”. Wychowawcy wzorem św. Jana Bosko starają się zapewnić chłopcom normalne życie, nadrobić braki w wychowaniu i wykształceniu oraz wzbudzić w nich aspiracje życiowe zgodnie z założeniami systemu prewencyjnego św. Jana Bosko. Wspierające twórczą aktywność i edukację działania duszpasterskie i charakterystyczny dla salezjanów model wychowawczy prowadzi do uzyskiwania wysokich efektów pracy wychowanków i wychowawców. Poczucie wzajemnych więzi uzdalnia do wierności wartościom najwyższym i niezmiennym oraz adekwatnej odpowiedzi na potrzeby wychowanków z zachowaniem właściwych odniesień do trzech filarów: religii, rozumu i serdecznej dobroci ${ }^{46}$.

\section{Podsumowanie}

Przytoczone przykłady pracy wychowawczo-edukacyjnej osób konsekrowanych na terenie diecezji tarnowskiej ukazują i potwierdzają, jak ważnym elementem misji Kościoła są te dzieła. Z jednej strony wskazują na uniwersalny i powszechny wymiar założeń i podstaw wychowania integralnego realizowanego w pedagogii katolickiej, będąc wypełnianiem wychowawczej funkcji Kościoła i w jego imieniu. Z drugiej zaś różnorodność charyzmatów ukazuje bogactwo, jakie zgromadzenia zakonne wnoszą do wspólnoty Kościoła i jego działalność ewangelizacyjną, edukacyjną i charytatywną. Ważną sprawąjest, aby same osoby konsekrowane w swej formacji duchowej i ludzkiej pogłębiały świadomość bogactwa potencjału, jaki Bóg złożył w ich wspólnoty, by z niego z łaską Bożą czerpały motywację i w nim znajdowały właściwą argumentację dla swej posługi edukacyjnej.

Świadomość odpowiedzialności za wykorzystanie charyzmatów, które otrzymaliśmy nie tylko dla własnego uświęcenia, lecz także dla służby innym, jest podstawą nie tylko spektakularnych działań, lecz przede wszystkim świadectwa wiary i życia, przy którym dopiero działania zyskają skuteczność. Wtedy sami wzrastając dzięki wiernej 
realizacji misji, staniemy się autentycznymi świadkami żyjącymi w tym świecie, ale nie według obyczajów tego świata. Tak możemy skutecznie wspierać rodziców, być przewodnikami dla młodych, służyć człowiekowi, by integralnie rozwijał się i formował w wymiarze ludzkim i nadprzyrodzonym.

Zachowując katolicką tożsamość naszej działalności edukacyjnej, tak ściśle powiązaną z naszą zakonną tożsamością, powinniśmy adekwatnie odpowiadać na współczesne potrzeby i wyzwania na polu edukacji. Nie możemy jednak dać sobie wmówić, że najważniejsze są standardy, metodyki, organizacja itp., lecz musimy na zawsze pozostać wierni najwyższemu prawu miłości Boga i człowieka. Trzeba nam na nowo przyjmować słowa Jana Pawła II: ,po to, by kochać i bronić człowieka, niepotrzebne są wam ideologie obce waszemu stanowi chrześcijańskiemu; bowiem w centrum orędzia, którego nauczacie, obecne jest zaangażowanie po stronie ludzkiej godności"47. Wypełniamy te zadania w ramach katechezy szkolnej i parafialnej, posługi opiekuńczo-wychowawczej we własnych placówkach, w poczuciu pełnienia misji niesienia ludziom pomocy, aby mogli osiągnąć pełnię życia chrześcijańskiego.

M. Loyola Opiela BDNP, Praca wychowawczo-edukacyjna osób konsekrowanych jako element misji Kościoła, [w:] Życie konsekrowane znakiem wiarygodności Kościola, red. ks. Andrzej Dudek, ks. Robert Kantor, Kraków 2016, s. 155-179 (Lumen Gentium, 2).

DOI: http://dx.doi.org/10.15633/9788374385725.10

47 Jan Paweł II, Przemówienie do nauczycieli i wychowawców, León, 4 marca 1983. 